\title{
Estimation of Population of Ten Selected Forest Tree Species Used by Communities around Kalinzu Forest Reserve, South-Western Uganda
}

\author{
Adalbert Aine-Omucunguzi ${ }^{1}$, Grace Kagoro Rugunda ${ }^{2}$, Dominic Byarugaba ${ }^{2}$ \\ ${ }^{1}$ Department of Biology, Kabale University, Kabale, Uganda \\ ${ }^{2}$ Department of Biology, Mbarara University of Science and Technology, Mbarara, Uganda \\ Email: aineomucunguzi@yahoo.co.uk \\ Received January 23 $3^{\text {rd }}, 2012$; revised April 12 $2^{\text {th }}, 2012$; accepted April $29^{\text {th }}, 2012$
}

\begin{abstract}
Local communities depend on Kalinzu Forest Reserve (KFR) for plant resources. This resource utilization affects the population of tree species in the forest. This study set out to estimate the population of ten tree species in the forest. Results of this study are hoped to provide a basis for studying future changes in population dynamics of the species. The ten species selected were: Newtonia buchananii, Cynometra alexandrei, Teclea nobilis, Prunus africana, Entandrophragma exelsum, Sapium ellipticum, Diospyros abyssinica, Zanthoxylum gilletii, Rytiginia kigeziensis and Spathodea nilotica. Their selection was based on the results of a study (Aine-Omucunguzi et al., 2010) about utilization of plant resources by the local people around KFR. Species with high demand from the local people were selected. Alternate nested quadrants along five line transects, were used to estimate the population. The plants were categorized into three classes as trees $(>5 \mathrm{~cm}$ diameter at breast height), saplings $(2 \mathrm{~cm}$ root collar diameter $-5 \mathrm{~cm}$ diameter at breast height) and wildings $(<2 \mathrm{~cm}$ root collar diameter). Population, population density, relative density, frequency, and relative frequency of each species were determined. Generally, the number of wildings, saplings and trees of each species increased away from the forest edge inwards. For all the species, wildings had the highest population density followed by saplings and then trees. Teclea nobilis had the highest number of individual per hectare, followed by Newtonia buchananii, while Rytiginia kigeziensis and Spathodea nilotica had the lowest number of individuals per hectare.
\end{abstract}

Keywords: Communities; Kalinzu Forest Reserve; Line Transect; Nested Quadrants; Population; Tree Species

\section{Introduction}

Kalinzu Forest reserve occupies parts of the counties of Bunyaruguru, Ruhinda and Igara in Bushenyi district, southwestern Uganda, with a population density 328 persons $\mathrm{km}^{-2}$. It was gazetted for a reserve in 1932 with an area of $461 \mathrm{~km}^{2}$, but some of the land was given off for tea estates development in 1954. The reserve now covers an area of $137 \mathrm{~km}^{2}$ (Howard, 1991). It lies on the eastern side of the Great Western Rift Valley at the edge of the escarpment overlooking Lake Edward. Kalinzu Forest Reserve is located between latitude $0^{\circ} 17^{\prime} \mathrm{N}$ and $0^{\circ} 30^{\prime} \mathrm{N}$ and between $30^{\circ} 00^{\prime} \mathrm{E}$ and $30^{\circ} 07^{\prime} \mathrm{E}$ and at an altitude ranging from 1200 to $1500 \mathrm{~m}$ above sea level. Kalinzu forest is one of the Afromontane forests of high biodiversity value in the Albertine rift. It is a home to twelve endemic species. These include nine butterfly species, one mammalian species and two tree species.

Local communities depend on Kalinzu Forest Reserve for plant resources. This resource utilization has an impact on the population of tree species in the forest. This study set out to assess the variation of wildings, saplings and trees of ten selected species with distance from the forest edge, and to estimate the population of each species, in order to provide data, that will be used as a basis to study future changes in population dynamics of the species. The ten species selected for the study were: Newtonia buchananii, Cynometra alexandrei, Te- clea nobilis, Prunus africana, Entandrophragma exelsum, Sapium ellipticum, Diospyros abyssinica, Zanthoxylum gilletii, Rytiginia kigeziensis and Spathodea nilotica. Their selection was based on the results of a study (Aine-Omucunguzi et al., 2010) about utilization of plant resources by the local people around Kalinzu Forest Reserve. Results of the study indicate that the above species are destructively and frequently harvested by fringe communities. The current study estimated the population of these species and analyzed it in terms of their harvesting demands, with a view of providing information that can be used as a basis to study future population dynamics of the species.

\section{Methods}

Nested quadrants along line transects were used to estimate the population of the species. Five line transects of $3.5 \mathrm{~km}$ each, with an interval of $1000 \mathrm{~m}$ were constructed using a tape measure. Each transect begun $30 \mathrm{~m}$ from the forest edge to eliminate edge effects. The plants were categorized into three classes as trees $(>5 \mathrm{~cm}$ diameter at breast height), saplings $(2 \mathrm{~cm}$ root collar diameter $-5 \mathrm{~cm}$ diameter at breast height) and wildings ( $<2 \mathrm{~cm}$ root collar diameter) (Alder \& Synnot, 1992; Nakibuka, 1994; Eilu, 1995). Eight alternate nested plots of $20 \mathrm{~m} \times 20 \mathrm{~m}$ with an interval of $500 \mathrm{~m}$ were constructed on each of the transects and the number of trees of each of the species was 
counted. Inside each of the $20 \mathrm{~m} \times 20 \mathrm{~m}$ plot, a $10 \mathrm{~m} \times 10 \mathrm{~m}$ plot was made and saplings of each of the selected species were counted. Inside each of the $10 \mathrm{~m} \times 10 \mathrm{~m}$ plot, a $5 \mathrm{~m} \times 5 \mathrm{~m}$ plot was made and wildings of each species were counted. In total, an area of 1.6 hectares was covered for trees, 0.4 hectares for saplings, and 0.1 hectares for wildings. The root collar diameter was measured using vernier calipers while diameter at breast height (DBH) was obtained by measuring the circumference of trees and saplings at breast height, and dividing the values obtained by pie (3.14).

The number and frequency of individuals in each category was estimated for each species by relating the number in the area sampled to the area of the whole forest $\left(137 \mathrm{~km}^{2}\right)$. The population, population density, relative density, frequency, and relative frequency of each species were calculated using the following formulae:

Population of a species $=$ population of wildings + population of saplings + population of trees in the forest;

Population density $=$ population of a species/total area sampled;

Relative density $=($ density of a species/density of all species sampled) $\times 100$;

Frequency $=$ number of plots with a species/total number of plots sampled;

Relative frequency $=($ Frequency of a species/total frequency of all species) $\times 100$.

\section{Results}

\section{Species Distribution}

120 plots were sampled. Of these, Teclea nobilis was found in 112 plots, Newtonia buchananii in 103 plots, Diospyros abyssinica in 97, Prunus africana in 94, Entandrophragma exelsum in 90, Cynometra alexandri in 76, Sapium ellipticum in 73 , Spathodea nilotica in 69, Rytiginia kigeziensis in 56, and Zanthoxylum gilletii in 10 plots.

Throughout the distance of $3500 \mathrm{~m}$ covered during this study, wildings of Newtonia buchananii were more than saplings and trees. The number of wildings increased from 26 at $0 \mathrm{~m}$ to 43 wildings at $500 \mathrm{~m}$, and then decreased to 37 wildings at $1000 \mathrm{~m}$. The number then increased steadily to 99 wildings at $3500 \mathrm{~m}$. The number of sapling was higher in plots deeper in the forest than those close to the forest edge. For each of the plots, saplings were more than the trees, except at $1000 \mathrm{~m}$, where the two were equal (18 individuals). The number of Newtonia buchananii trees decreased slightly from 8 trees at $0 \mathrm{~m}$ to 5 trees at $500 \mathrm{~m}$. The number increased to 18 trees at $1000 \mathrm{~m}$, and then decreased to 14 trees at $1500 \mathrm{~m}$. The number then increased steadily to 43 trees at $3500 \mathrm{~m}$ into the forest (Figure 1). Wildings of Newtonia buchananii had the highest frequency, followed by saplings, and trees had the lowest frequency (Table 1).

The number of Cynometra alexandrei wildings increased steadily from 5 individuals at $0 \mathrm{~m}$ to 66 individuals at $3500 \mathrm{~m}$. The number of saplings decreased from 11 saplings at $0 \mathrm{~m}$ to 0 at $1000 \mathrm{~m}$, and then increased steadily to 25 saplings at $2500 \mathrm{~m}$. It then decreased to 23 saplings at $3000 \mathrm{~m}$, and then increased to 34 saplings at $3500 \mathrm{~m}$ into the forest. The number of $C y$ nometra alexandrei trees decreased from 6 individuals at $0 \mathrm{~m}$ to 3 individuals at $1000 \mathrm{~m}$ into the forest. The number then increased steadily to 35 trees at $3500 \mathrm{~m}$ into the forest (Figure 2).

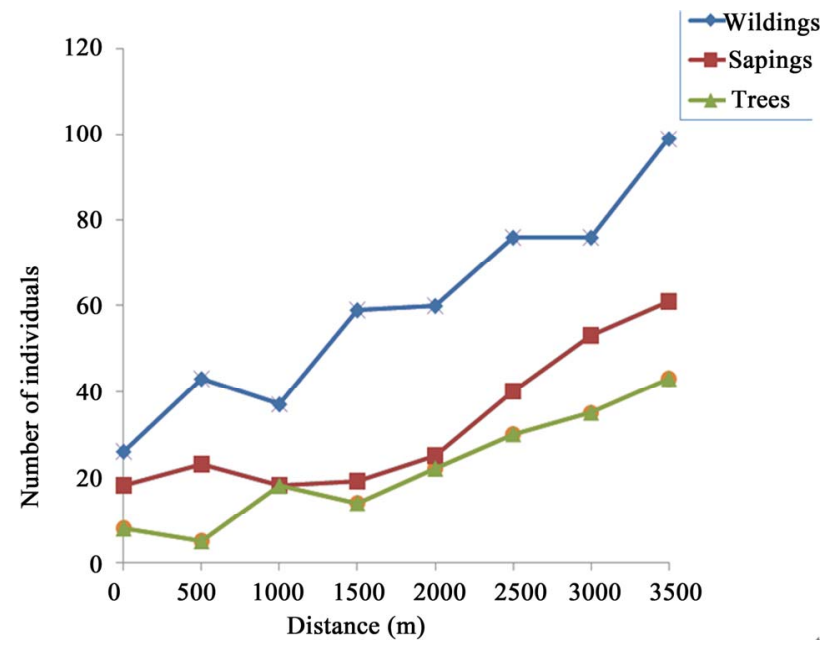

Figure 1.

Variation of Newtonia buchananii with distance from forest edge.

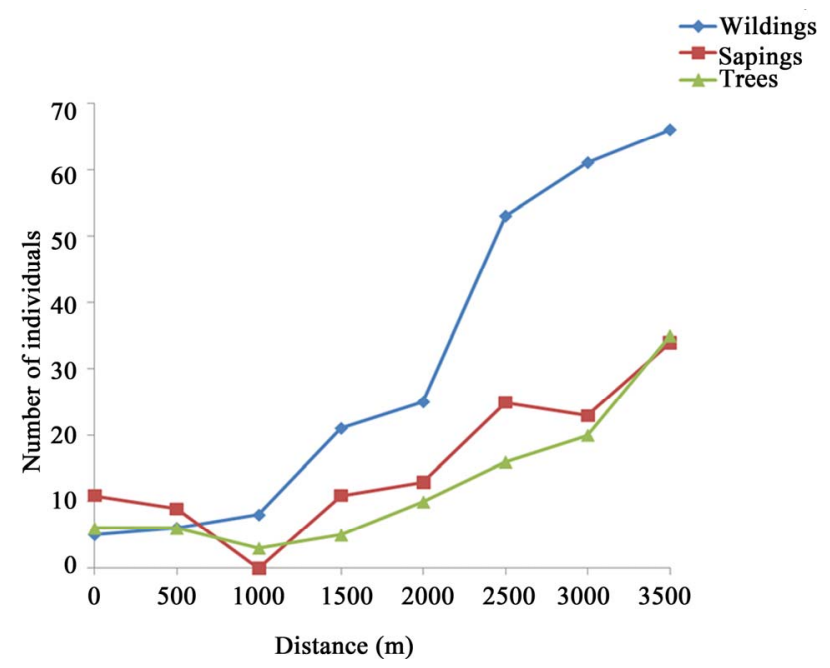

Figure 2.

Variation of Cynometra alexandrei with distance from the forest edge.

Saplings of Cynometra alexandrei had the highest frequency in the forest, followed by wildings and then trees (Table 1).

The number of wildings of Teclea nobilis decreased slightly from 26 wildings at $0 \mathrm{~m}$ to 24 wildings at $500 \mathrm{~m}$. The number then increased steadily to 108 wildings at a distance of $3500 \mathrm{~m}$ into the forest. The number of Teclea nobilis saplings increased steadily from 8 saplings at $0 \mathrm{~m}$ to 37 saplings at $1000 \mathrm{~m}$. The number decreased to 20 saplings at $1500 \mathrm{~m}$, and then increased steadily to 53 saplings at $3500 \mathrm{~m}$ into the forest. The number of tree increased from 28 at $0 \mathrm{~m}$ to 48 trees at $1000 \mathrm{~m}$. The number then decreased to 43 trees at $1500 \mathrm{~m}$, and then increased steadily to 78 trees at $3500 \mathrm{~m}$ into the forest (Figure 3). Wildings of Teclea nobilis had the highest frequency followed by saplings, and then trees (Table 1).

The number of Prunus africana wildings increased from 9 at $0 \mathrm{~m}$ to 20 wildings at $500 \mathrm{~m}$. The number decreased sharply to 7 wildings at $1500 \mathrm{~m}$. It then increased steadily to 53 wildings at $3500 \mathrm{~m}$. The number of saplings decreased from 22 at $0 \mathrm{~m}$ to 8 saplings at $1500 \mathrm{~m}$. This number increased steadily to 32 saplings at $3500 \mathrm{~m}$. The number of Prunus africana trees in- 


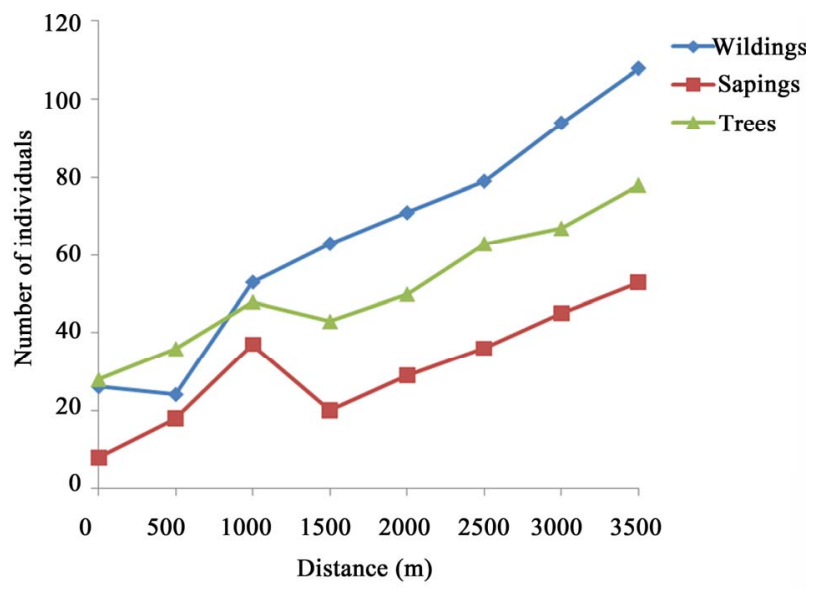

Figure 3.

Variation of Teclea nobilis with distance from the forest edge.

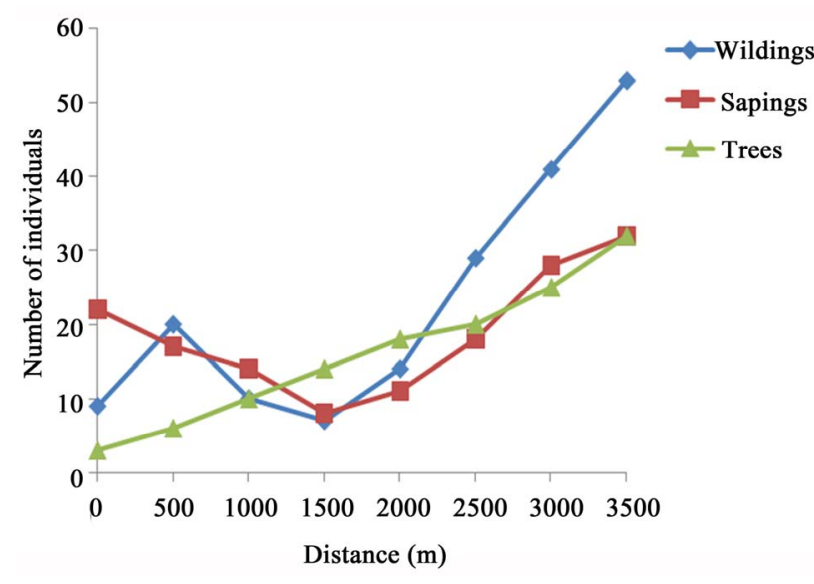

Figure 4.

Variation of Prunus africana with distance from the forest edge.

Table 1.

Total population of each species in the forest.

\begin{tabular}{|c|c|c|c|c|c|}
\hline Scientific name & Number in forest & Population density & Relative density & Frequency & Relative frequency \\
\hline Teclea nobilis & $82,816,500$ & 5430.6 & 22.3 & 166,113 & 12.77 \\
\hline Newtonia buchananii & $73,425,438$ & 5359.8 & 19.8 & 164,143 & 12.62 \\
\hline Cynometra alexandrei & $42,427,188$ & 3096.9 & 11.4 & 122,872 & 9.44 \\
\hline Diospyros abyssinica & $37,161,250$ & 2712.5 & 10.0 & 140,254 & 10.78 \\
\hline Prunus africana & $30,140,000$ & 2200 & 8.1 & 149,416 & 11.48 \\
\hline Entandrophragma exelsum & $29,266,625$ & 2136.6 & 7.9 & 134,432 & 10.33 \\
\hline Zanthoxylum gilletii & $27,408,563$ & 2000.6 & 7.4 & 137,086 & 10.54 \\
\hline Sapium ellipticum & $26,115,625$ & 1906.3 & 7.0 & 119,275 & 9.17 \\
\hline Rytiginia kigeziensis & $11,371,000$ & 830 & 3.1 & 82,628 & 6.35 \\
\hline Spathodea nilotica & $11,353,875$ & 828.8 & 3.1 & 84,940 & 6.53 \\
\hline
\end{tabular}

Population of a species shown in Table $\mathbf{1}$ is the sum of the population of wildings, saplings and trees for each species.

creased steadily from 3 at $0 \mathrm{~m}$ to 32 trees at $3500 \mathrm{~m}$ (Figure 4). Wildings of this species had the highest frequency, followed by saplings, and trees had the lowest (Table 1).

The number of Entandropgragma exelsum wildings was 10 individuals at $0 \mathrm{~m}$. This decreased slightly to 10 wildings at 500 $\mathrm{m}$, and then increased steadily to 53 wildings at $3500 \mathrm{~m}$. The number of saplings was 5 at $0 \mathrm{~m}$. This increased to 11 saplings at $500 \mathrm{~m}$, and then decreased to 5 saplings at $1000 \mathrm{~m}$. The numbers increased to 10 saplings at $2000 \mathrm{~m}$, and then decreased slightly to 9 saplings at $2500 \mathrm{~m}$. The number then increased to 24 saplings at $3500 \mathrm{~m}$. The number of tree at $0 \mathrm{~m}$ was 3 . This decreased to 2 trees at $500 \mathrm{~m}$, and then increased steadily to 29 trees at $3500 \mathrm{~m}$ (Figure 5). Wildings of Entandropgragma exelsum had the highest frequency, followed by saplings, and then trees (Table 1).

The number of wildings of Sapium ellipticum was 14 at $0 \mathrm{~m}$. This remained constant up to $500 \mathrm{~m}$, and then decreased sharply to 2 wildings at $1000 \mathrm{~m}$. The number then increased steadily to 43 wildings at $3500 \mathrm{~m}$. The number of saplings of Sapium ellipticum was 4 at $0 \mathrm{~m}$; this decreased to 1 sapling at
$500 \mathrm{~m}$, and then increased 3 saplings at $1000 \mathrm{~m}$. The number decreased to 2 saplings at $1500 \mathrm{~m}$ and then increased to 11 saplings at $2000 \mathrm{~m}$. It then decreased slightly to 10 saplings at $2500 \mathrm{~m}$, from where it increased steadily to 27 saplings at 3500 $\mathrm{m}$. The number of Sapium ellipticum trees was 1 at $0 \mathrm{~m}$. This increased to 2 trees at $500 \mathrm{~m}$, and then decreased again to 1 tree at $1000 \mathrm{~m}$, from where the number increased steadily to 23 trees at $3500 \mathrm{~m}$ (Figure 6). The wildings of Sapium ellipticum had the highest frequency, followed by saplings, and trees had the lowest frequency (Table 1).

The number of Diospyros abyssinica wildings decreased from 11 at $500 \mathrm{~m}$ and remained constant up to $1000 \mathrm{~m}$. The number then increased steadily to 55 wildings at $3500 \mathrm{~m}$. The number of saplings decreased from 16 at $0 \mathrm{~m}$ to 0 at $1000 \mathrm{~m}$. The number then increased steadily to 34 saplings at $3500 \mathrm{~m}$. The number of tree dcreased from 18 at $0 \mathrm{~m}$ to 17 trees at 500 $\mathrm{m}$. The number then increased steadily to 51 trees at $3500 \mathrm{~m}$ (Figure 7). Wildings of Diospyros abyssinica had highest frequency, followed by saplings, while trees had the lowest (Table 1). 


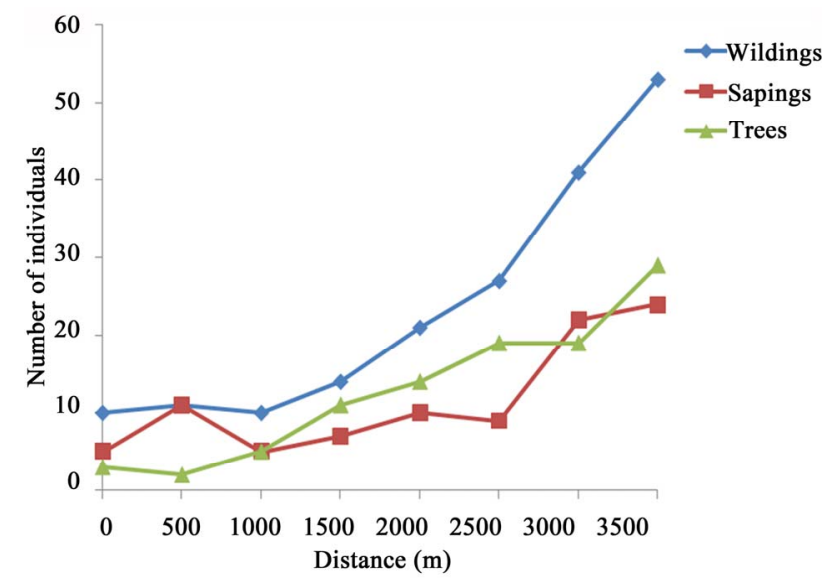

Figure 5.

Variation of Entandrophragma exelsum with distance from the forest edge.

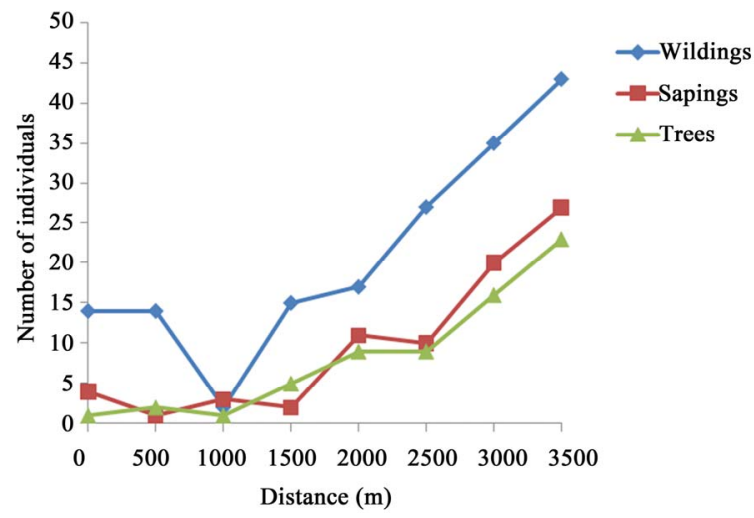

Figure 6.

Variation of Sapium ellipticum with distance from the forest edge.

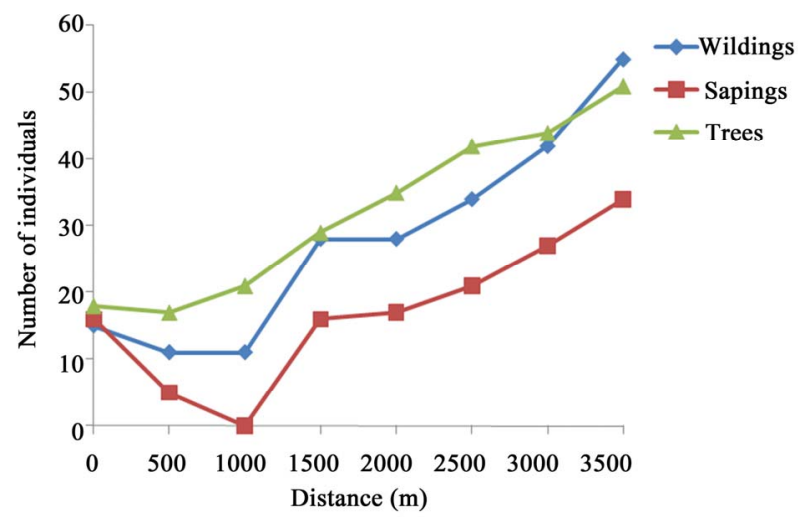

Figure 7.

Variation of Diospyros abyssinica with distance from the forest edge.

The number of wildings of Zanthoxyllum gilletii was 4 at $0 \mathrm{~m}$; and increased to 7 wildings at $500 \mathrm{~m}$. This decreased to 6 wildings at $1000 \mathrm{~m}$ and remained constant up to $1500 \mathrm{~m}$. The number then increased steadily to 49 wildings at $3500 \mathrm{~m}$. The number saplings was 9 at $0 \mathrm{~m}$. This remained constant up to $500 \mathrm{~m}$; and increased to 15 saplings at $1000 \mathrm{~m}$. This decreased to 6 saplings at $1500 \mathrm{~m}$, and then increased steadily to 27 saplings at $3500 \mathrm{~m}$. The number of trees of Zanthoxyllum gilletii was 14 at $0 \mathrm{~m}$; this decreased to 6 trees at $500 \mathrm{~m}$; and then increased steadily to 57 trees at $3500 \mathrm{~m}$ (Figure 8). Wildings of Zanthoxyllum gilletii showed the highest frequency, followed by saplings. Trees of this species showed the lowest frequency (Table 1).

The number of wildings of Rytiginia kigeziensis increased from 0 at $0 \mathrm{~m}$ to 4 wildings at $500 \mathrm{~m}$; this decreased to 2 wildings at $1000 \mathrm{~m}$. The number then increased steadily to 23 wildings at $3500 \mathrm{~m}$. The number of saplings increased from 1 to 5 at $1500 \mathrm{~m}$; and remained constant up to $2500 \mathrm{~m}$, and then increased to 13 saplings at $3500 \mathrm{~m}$. The number of Rytiginia kigeziensis trees increased from 2 at $0 \mathrm{~m}$ to 3 trees at $500 \mathrm{~m}$. The number decreased to 1 tree at $1000 \mathrm{~m}$, and then increased to 6 trees at $2000 \mathrm{~m}$, from where it dcreased to 5 trees at 2500 $\mathrm{m}$, and then increased to 7 trees at $3500 \mathrm{~m}$ (Figure 9). The frequency of wildings of Rytiginia kigeziensis was the highest, followed by saplings. Trees had the lowest frequency in this category (Table 1).

The number of wildings of Spathodea nilotica was 0 from 0 $\mathrm{m}$ to $1500 \mathrm{~m}$ into the forest. The number then increased steady until it was 29 at $3500 \mathrm{~m}$ into the forest. The number of saplings decreased from 1 at $0 \mathrm{~m}$ to 0 at $500 \mathrm{~m}$; this remained constant up to $1000 \mathrm{~m}$. The number increasedd to 10 saplings at $2000 \mathrm{~m}$ and remained constant up to $2500 \mathrm{~m}$, from where it increased to 13 saplings at $3500 \mathrm{~m}$. The number of Spathodea nilotica trees was 8 at $0 \mathrm{~m}$ and remained constant up to $500 \mathrm{~m}$. It then decreased to 3 trees at $1000 \mathrm{~m}$; the number then increased steadily to 21 trees at $2500 \mathrm{~m}$. It then decreased slightly to 20 trees at $3000 \mathrm{~m}$, and again increased to 28 trees at $3500 \mathrm{~m}$

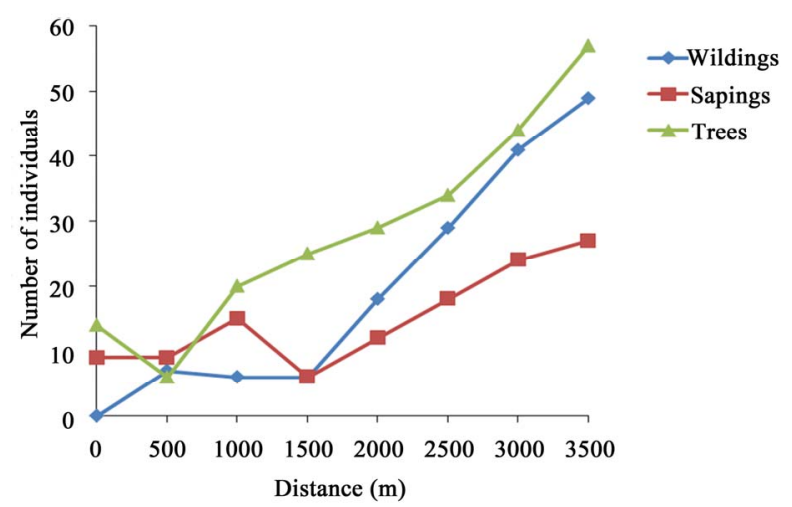

Figure 8.

Variation of Zanthoxyllum gilletii with distance from the forest edge.

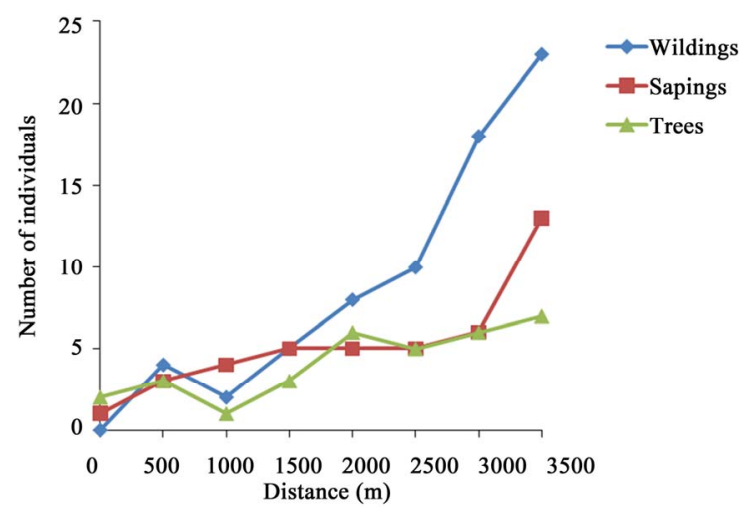

Figure 9.

Variation of Rytiginia kigeziensis with distance from the forest edge. 
(Figure 10). Wildings of Spathodea nilotica had the highest frequency, followed by saplings, while trees had the lowest (Table 1).

\section{Estimation of Population of Each Species}

For all the species, wildings had the highest population density, followed by saplings, while trees had the lowest population density. Teclea nobilis had the highest population density of 5430.6 individuals per hectare. Newtonia buchananii followed with a population density of 5359.8 individuals per hectare. Cynometra alexandrei had a population density of 3096.9 individuals per hectare. Diospyros abyssinica had a density of 2712.5 individuals per hectare, Prunus africana followed with a density of 2200 individuals per hectare. Entandrophragma exelsum had 2136.6 individuals per hectare, Zanthoxylum gilletii had a density of 2000.6 individuals per hectare, Sapium ellipticum followed with a density of 1906.3 individuals per hectare, Rytiginia kigeziensis had a density of 830 individuals per hectare and Spathodea nilotica had the lowest population density of 828.8 individuals per hectare (Figure 11). The overall frequency of the species followed a trend similar to that of population density.

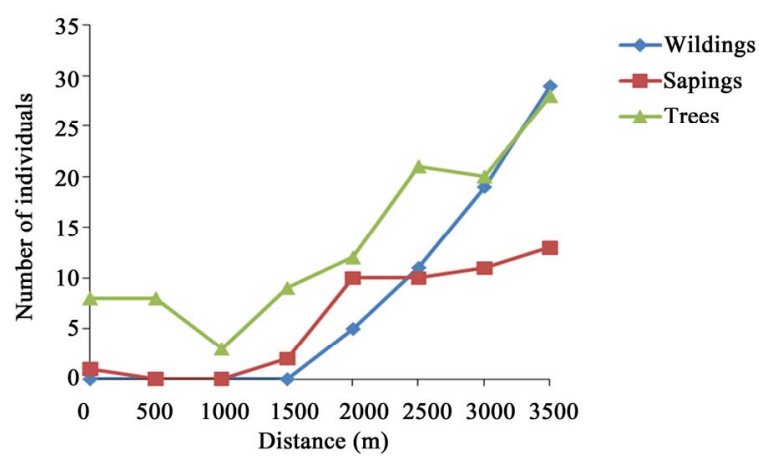

Figure 10.

Variation of Spathodea nilotica with distance from the forest edge.

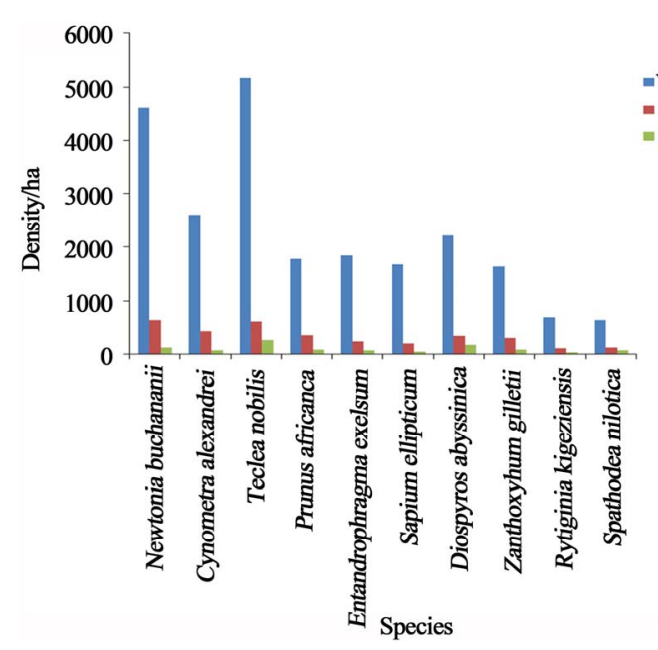

Population density for each category was obtained by dividing the number of individuals in the category by the total area sampled.

\section{Figure 11.}

Comparison of population density of wildings, saplings and trees per species.

\section{Discussion}

The number of plants in each plant category generally increased away from the forest edge inwards. There are two possible explanations to this trend. First, it could be due to edge effects where micro-climatic conditions affect the growth of the tree species under study. Secondly, it could be due to the harvesting behaviour of people in the forest fringe communities. It is likely, that people tend to avoid walking long distances in the forest and thus first harvest tree resources they come across as soon as they enter the forest. This is probably the reason why plots that were deep in the forest generally had more individuals than those that were close to the forest edge. The low number of wilding near the forest edge can be attributed to two factors; first, as people move and harvest tree resources, the wildings are either cut to pave way or stepped on and eventually die. Second, some trees are harvested before they bear seeds and this reduces the number of wildings. Some plots deep in the forest however had fewer individuals than those close to the edge. This is because, at times harvesters are interested in plants of a particular size or level of maturity, and in such cases, they tend to ignore those that are close to the forest edge and go to harvest deep in the forest. This was particularly common with species of medicinal value. This mode of harvest for instance explains why Diospyros abyssinica had 16 saplings at a distance of $0 \mathrm{~m}$ and no saplings at $1000 \mathrm{~m}$ into the forest (Figure 7). The variation of saplings of Prunus africana with distance (Figure 4) can also be attributed to the mode of harvest used by the local people, where the removal of bark affects the reproductive performance of trees.

For species like Rytiginia kigeziensis, Spathodea nilotica, Prunus africana, and Zanthoxylum gilletii whose bark is of medicinal value, the trend may be attributed to the fact that bark used for medicinal purposes is mainly harvested from mature trees and in this case, harvesters have to particularly look for such trees, in which case they may be forced to move deep into the forest, if the trees are not near the forest edge. This, for example, explains why Zanthoxylum gilletii had 14 trees at $0 \mathrm{~m}$ and 6 trees $500 \mathrm{~m}$ into the forest (Figure 8). Some of the plants, especially wildings are destroyed during the harvesting process. This may for instance explain why Sapium ellipticum had 14 wildings at a distance of $0 \mathrm{~m}$ and 02 wildings at $1000 \mathrm{~m}$ (Figure 6). Resource harvesters normally cut the understorey to create paths. It's mainly the wildings and saplings that are affected. Other plants are destroyed when trees are cut down.

It is important to note however, that this plant distribution cannot entirely be attributed to human disturbance. There are many other factors that influence plant distribution. They include; the nature of the soil, forest canopy cover, altitude, and mode of dispersal among others. These factors vary with in the forest, and therefore shape the distribution of plants in different parts of forest. If a species is shade tolerant, majority of its individuals will be found under thick canopy cover, whereas most individuals of a light tolerant species will be found where there are gaps. This agrees with findings of (Fayle et al., 2009). Likewise, a species that is dispersed by self explosion will have most of its individuals confined to one area of the forest, while a species that is dispersed by animals may have its individuals widely spread in the forest. (Bleher et al., 2002) emphasize that the mode of dispersal of a species influences its distribution in a forest. Soil conditions influence the rate of germination. More individuals germinate where the soil conditions are favourable 
(Nazre et al., 2009). It is important to note that tree populations with low densities and clumped distributions are at risk in the face of increased human dependence on forest products.

Frequency is a good measure of species distribution. Species with high frequencies are frequently encountered in the forest, and are widely distributed, while those with very low frequencies are either confined to particular parts of the forest, or are scarce. This kind of distribution is usually due to high rate of harvest, nature of soil, mode of dispersal, or altitude. The high frequency of Teclea nobilis (Table 1) for instance, suggests that it is widely distributed in the forest, while the low frequency of Spathodea nilotica is an indication that it is not common in the forest. Comparing the frequency of wildings, saplings and trees of a given species gives an insight into the stage of the plant that is affected most by harvesting. The low frequency of trees in this study suggests that they are the most affected by harvesting, and the high frequency of wildings suggests that they are the least affected by harvesting, while the saplings are intermediate. The high frequency of wildings for most of the species suggests that they are widely distributed in the forest and that their numbers are still high due to low levels of harvest. The low frequency of Cynometra alexandrei wildings compared to other species is an indication that the population of this species is on the decline. This could probably be attributed to the high demand of this species for fuel wood. Most of the trees of this species are harvested before fruiting and this has greatly reduced its seed bank.

\section{Conclusion and Recommendations}

For all the species studied, the low number of trees implies that there are fewer individuals contributing to the forest seed bank. If the rate of tree harvest is not regulated, the seed bank may in the long run be depleted. However, the high number of wildings and saplings suggests that the population of most of these species is generally stable. It's worth noting however, that human disturbance may in some cases increase resilience of some species. Effective conservation of these tree species requires strategies that specify the age and size of plants from which to harvest, and the frequency of harvest. Since wildings are normally destroyed during the harvesting process, it's important to also specify parts of the forest in which harvesting is allowed. These parts will then need effective monitoring. All this will only be possible, if the local people are involved in the decision making process and management of the forest.

Changes in population can be used to show the intensity of harvesting of a species; however it was quite hard in this particular study, because no previous data was available to compare populations of particular species in order to determine the population decline or increase over time. It is therefore hoped that the results of this study will provide a basis for studying changes in the population of these ten species. Never the less, the low population of Zanthoxylum gilletii, Rytiginia kigeziensis and Spathodea nilotica, can be attributed to the destructive methods used to harvest their bark, which in most cases result into death of the affected plants.

Species with low numbers are mainly those with medicinal value and they have been massively and destructively harvested for a long time. This has tremendously affected their distribution in the forest. They are now left very deep in the forest. There is a need to sensitize the resource harvesters about responsible harvesting of plant resources. This will minimize the destruction of the understorey during the harvesting process. There is need to incorporate the resource users in the management process of Kalinzu Forest Reserve if their negative impacts on the forest are to be minimized. Their incorporation requires a clear understanding of the socio-economic attributes that shape their forest resource demands.

\section{Acknowledgements}

This work was funded by the Toyota Foundation of Japan through the Kalinzu Forest Project. We are grateful to Professor Takeshi Furuichi and Associate Professor Chie Hashimoto of the Kalinzu Forest Project for the financial and technical help they gave to us. We are also indebted to the local people around Kalinzu Forest Reserve for all the assistance extended to us during the study.

\section{REFERENCES}

Aine-Omucunguzi, A., Rugunda, G. K., \& Byarugaba, D. (2010). Utilization of forest plant resources by the local people around Kalinzu forest reserve, south-western Uganda. African Journal of Ecology, 48, 819-821.

Alder, D., \& Synnot, T. J. (1992). Permanent sample plot techniques for mixed tropical forest. Teopical Forestry Paper No. 25, Oxford: Oxford Forestry Institute.

Bleher, B., Oberrath, R., \& Bohning-Gaese, K. (2002). Seed dispersal, breeding systems, tree density and the spatial pattern of trees-A simulation approach. Basic and Applied Ecology, 3, 115-123. doi:10.1078/1439-1791-00088

Eilu, G. (1995). The natural regeneration of canopy tree species following human disturbance in Bwindi impenetrable forest, Uganda. Master's thesis, Kampala: Makerere University.

Fayle, T. M., Chung, A. Y. C., Dumbrell, A. J., Eggleton, P., \& Foster W. A. (2009). The effects of rain forest canopy architecture on the distribution of epiphytic ferns (Asplenium spp.) in Sabah Malaysia. Biotropica, 41, 676-681. doi:10.1111/j.1744-7429.2009.00523.x

Howard, P. (1991). Nature conservation in Uganda's tropical forest reserves. Gland and Cambridge: International Union for Conservation of Nature.

Nakibuka, M. (1994). Some aspects of tropical rain forest regeneration following encroachment in the Mabira forest reserve. Dissertation, Kampala: Makerere University.

Nazre, M., Latiff, A., \& Mohamad-Roslan, M. K. (2009). Effects of topography and soil on the distribution of under canopy trees of Garcinia (Guttiferae) in lowland forest of Peninsular Malaysia. International Journal of Botany, 5, 287-294. 